\title{
The Influence of Different Light Wavelengths on Growth, Enzymes Activity and Photosynthesis of the Marine Microalga Dunaliella parva W.Lerche 1937
}

\author{
Mostafa El-Sheekh*
}

Samha Dewidar

Azza Hamad

Botany Department, Faculty of Science, Tanta University, Tanta 31527, Egypt

*Corresponding author: mostafaelsheikh@ @cience.tanta.edu.eg, samhadowidar@ hotmail.com, drazzaaa@yahoo.com

*ORCID ID: https://orcid.org/0000-0002-2298-6312,

Received 7/6/2020, Accepted 27/12/2020, Published Online First 11/1/2021, Published 1/6/2021

\begin{abstract}
:
Light is an important factor that influences the growth and photosynthetic efficiency of microalgae; however, little is known about how light intensity together with the wavelength affect the photosynthetic capacity and growth of marine microalgae. In the present study, the growth of the marine green microalga Dunaliella parva was studied and optimized under different light intensities $\left(25 \sim 70 \mu \mathrm{mol} \mathrm{m} \mathrm{m}^{-2}\right)$ and qualities (blue, green, and red) in comparison with white light at $40 \mu \mathrm{mol} \mathrm{m} \mathrm{m}^{-2}$ as a control. The growth was monitored by counting the cell number, pigment content, $\mathrm{Chl} a$, $\mathrm{Chl} b$, and carotenoids concentrations. The optimal growth and highest photosynthetic efficiency $(\mathrm{Fv} / \mathrm{Fm})$ were recorded at a light intensity of $40 \mu$ mol m $\mathrm{m}^{-2}$, white light, and $1.25 \mathrm{M} \mathrm{NaCl}\left(1.47\right.$ and $0.678 \times 10^{6}$ cell $\mathrm{mL}^{-1}$, respectively). The activity of antioxidant enzymes, including catalase and peroxidase, as well as ascorbate content, showed the highest values of $0.190 \mu \mathrm{M} / \mathrm{min} . \mathrm{mg} \mathrm{Chl}, 0.434$ and $13.3 \mathrm{mg} / \mathrm{g}$ f.wt. respectively, under the green light, which confirmed the presence of environmental stresses.
\end{abstract}

Key words: Antioxidant enzymes, Dunaliella, Light intensity, Light quality, Photosynthesis.

\section{Introduction:}

The halotolerant, unicellular biflagellate green alga Dunaliella is distinguished morphologically by the absence of a rigid cell wall, contractile vacuoles, and its large pyrenoid. It has two equal flagella, one cup-shaped chloroplast, an anterior nucleus, an eye-spot (1). Dunaliella is the only eukaryotic photosynthetic marine microalga that exhibits special characteristics by synthesis and varying the intracellular concentration of glycerol to enable it to grow over an extremely wide range of salt concentrations (2). Light is the most important factor influencing the growth of all photosynthetic organisms, including Dunaliella sp. (3). It is well known that Dunaliella salina is significantly affected by the light intensity, which is an important factor regulating pigment production in the cells. When light intensity increased the chlorophyll-a production increased as compared with the low light intensity (4). Coesel et al., (5) observed a linear increase in the total carotenoids content of Dunaliella salina when light intensity increased.

The low light intensity is known to increase the large photosynthetic unit, chlorophyll antenna size of both PSI and PSII, and cells is found to be normally converted to deep green as pigments increased in Dunaliella salina (6). On the other hand, the high light intensity promotes the photosynthetic smaller chlorophyll antenna size, and cells are yellow-green in color (7). Exposure of $D$. bardwill to photon flux density ranges over 100 to $4000 \mu \mathrm{mol} \mathrm{m} \mathrm{m}^{-2}$ increasing total carotenoids reaching 4.5 fold. The over-accumulation of $\beta$ carotene in Dunaliella cells protect the algal cells against damage mainly to protect the principal pigment Chl. $a$ by high irradiation (8).

The effect of different light qualities (White, Blue, Green, Red, and yellow light) on the red alga Porphyra leucosticta was investigated by Korbee et al. (9) by measuring the photosynthetic efficiency of PSII $\left(\mathrm{F}_{\mathrm{v}} / \mathrm{F}_{\mathrm{m}}\right)$, pigments, protein, and the UVabsorbing mycosporine-like amino acids (MAAs). They found that the lowest photosynthetic efficiency and growth rate were detected under blue light, but the higher value was detected under red and white lights. They also concluded that blue light promoted the highest accumulation of nitrogen metabolism derived compounds i.e., MAAs, phycoerythrine, and proteins in Porphyra 
leucosticta previously grown in ammonium enriched medium. Recently, Palacios et al. (10) studied the effect of light intensity on the photosynthetic and growth of the marine alga Nannochloropsis oculata (Phylum: Ochrophyta), and they found that cultures were grown under a range of light intensities from 20 to $200 \mu \mathrm{mol}$ photons $\mathrm{m}^{-2} \mathrm{~s}^{-1}$ showed a doubling in the content of Chl. $a$, and consequently increased the oxygen evolution capacity.

The aim of this work is to assess the optimal growth conditions of Dunaliella parva under different light intensities and light qualities as monitored by optical density, cell number, and determination of pigments content. The photosynthetic efficiency ( $\mathrm{Fv} / \mathrm{Fm})$, the activity of enzymatic antioxidant (Catalase, Peroxidase, and ascorbic acid oxidase), and the content of nonenzymatic antioxidant (Ascorbate content) were also studied under different light quantities and qualities.

\section{Material and Methods: Algal culturing}

The pure and identified culture of Dunaliella parva was obtained from NIES Collection, Tsukuba, JAPAN. The alga was maintained on MH medium (11) and, after being checked with the sterilized medium, it was used as an inoculum for algal growth in a liquid nutrient medium (MH) under sterilized conditions.

For the proper maintenance of the algal cultures, the agar slants were inoculated and left under the light of $40 \mu \mathrm{mol} \mathrm{m}^{-2} \mathrm{~s}^{-1}$ at room temperature $\left(25 \pm 3{ }^{\circ} \mathrm{C}\right)$.

One liter of the liquid nutrient medium was poured into two liter Erlenmeyer Pyrex- glass flasks. The culture flasks were plugged with cotton and sterilized in an autoclave at $121{ }^{\circ} \mathrm{C}$ and 1.5 atoms for $20 \mathrm{~min}$. After cooling, the flasks were inoculated with $200 \mathrm{ml}$ of bacteria-free stock culture and incubated under continuous light provided by fluorescent lamps at a light intensity of $40 \mu \mathrm{mol} \mathrm{m} \mathrm{m}^{-2} \mathrm{~s}^{-1}$. The growth and pigment production were determined until the end of the experimental period (16 days) for the growth curve. However, determination of growth and pigment content for all subsequent experiments was carried out on the $10^{\text {th }}$ day.

\section{Effect of light intensity}

The culture flasks (batch culture) of D. parva were placed on shelves illuminated by fluorescent lamps. The light intensity was adjusted to $(25,40$, and $70 \mu$ mol $\mathrm{m}^{-2} \mathrm{~s}^{-1}$ ) by changing the distance from fluorescent lamps. The light intensity was measured using LI-185 B Quantum/Radiometer photometer. Effect of light quality
Erlenmeyer flasks $(500 \mathrm{ml})$ containing 300 $\mathrm{ml}$ MH medium were inoculated with an initial volume $(10 \mathrm{ml})$ of a pre-culture of Dunaliella parva. The flasks were covered with blue (BL), red (RL), and green (GL) cellophane paper according to Vijaya and Anand (12) and incubated under controlled laboratory conditions $\left(25 \pm 3{ }^{\circ} \mathrm{C}\right.$ and light intensity of $400 \mu \mathrm{mol} \mathrm{m}^{-2} \mathrm{~s}^{-1}$ ). White light (WL) was used as the control.

\section{Determination of growth}

The growth of $D$. parva was determined by monitoring cell count using the haemocytometer slide. Counts were estimated as a number of cells $/ \mathrm{ml}$ culture, and counts were made with at least 5 replicates (13).

\section{Relative growth rate}

The relative growth rate $\left(\mathrm{k}^{\prime}\right)$ was calculated according to Robert (13) from the following formula:

$$
K^{\prime}=[\log N-\log N 0] / t
$$

$\mathrm{N}=$ Number of cells/ml after time (t) (days).

$\mathrm{N}_{0}=$ Number of cells $/ \mathrm{ml}$ at the initial time.

Generation time: The generation time $(\mathrm{G})$ is the time needed for doubling the number of cells. It was calculated according to the following formula proposed by Fogg (14):

Where:

$$
\text { G.T }=0.301 / \mathrm{K}^{\prime}
$$

$\mathrm{K}^{\prime}=$ the relative growth rate.

Number of recycling: The number of recycling for doubling the cells within a definite time could be calculated as follows:

$$
\text { No. of recycling }=\mathrm{T} / \mathrm{G}
$$

Where:

$\mathrm{T}=$ time from the beginning to the end of the experiment and $\mathrm{G}=$ mean doubling time during that time.

1.1.1. Growth rate: The growth rate (R) (number of divisions/ day) was calculated by using the equation proposed by Robert (13):

Where:

$$
\mathrm{R}=\left(3.322 /\left(\mathrm{t}_{2}-\mathrm{t}_{1}\right)\right) \times \log \left(\mathrm{N}_{2} / \mathrm{N}_{1}\right)
$$

$3.322=$ growth constant, $\mathrm{t}_{1}=$ time at the beginning of the experiments, $t_{2}=$ time at the end of the experiment, $\mathrm{N}_{1}=$ number of cells $/ \mathrm{ml}$ culture at $\mathrm{t}_{1}$ and $\mathrm{N}_{2}=$ number of cells $/ \mathrm{ml}$ culture at $\mathrm{t}_{2}$.

Mean growth rate: the mean growth rate (R') (number of divisions / definite time "days") was calculated from the formula proposed by Robert (13):

$$
\mathrm{R}=\left(3.322 /\left(\mathrm{t}-\mathrm{t}_{0}\right)\right) \times \log \left(\mathrm{N} / \mathrm{N}_{0}\right)
$$

Where:

$3.322=$ growth constant, $t_{0}=$ time at the beginning of the experiments (days), $t=$ time at the end of the 
experiment (days), $\mathrm{N}_{0}=$ number of cells $/ \mathrm{ml}$ culture at $\mathrm{t}_{0}$ and $\mathrm{N}=$ number of cells $/ \mathrm{ml}$ culture at $\mathrm{t}$.

\section{Estimation of photosynthetic pigments}

Chlorophyll $a, b$ and carotenoids were determined spectrophotometrically using the method recommended by Mckinney (15). The extract was measured against blank of free methanol $(100 \%)$ at 650, 665 and $452 \mathrm{~nm}$. It was possible to determine the concentration of each pigment fraction Chlorophyll $a, b$ and carotenoids as $\mu \mathrm{g} / \mathrm{ml}$ algal suspension using the following equations:

Chlorophyll $-a=10.3 \mathrm{E}_{665}-0.918 \mathrm{E}_{650}$

Chlorophyll- $b=19.7 \mathrm{E}_{650}-4.87 \mathrm{E}_{665}$

Carotenoids $=4.2 \mathrm{E}_{452}-(0.0246 \mathrm{chl}-\mathrm{a}+0.426$ chl-b)

Where $\mathrm{E}=$ The reading of sample on Unico UV2000 spectrophotometer.

\section{Measurement of Chlorophyll a fluorescence}

The chlorophyll a fluorescence was measured at room temperature. A known volume of algal culture having a known chlorophyll concentration was pipetted out and centrifuged at $3000 \mathrm{rpm}$ for $20 \mathrm{~min}$. The supernatant was decanted, and the pellet was placed on a piece of dressing imposed on filter paper with a known and constant diameter at all measurements. Using a modulated light MINI-PAM portable fluorometer (Walz, Germany), the initial fluorescence $\left(\mathrm{F}_{0}\right)$, maximum fluorescence $\left(\mathrm{F}_{\mathrm{m}}\right)$ were analyzed, and quantum efficiency of open photosystem II centresquantum yield $\left(\mathrm{F}_{\mathrm{v}} / \mathrm{F}_{\mathrm{m}}\right)$ was calculated. The algal discs were previously adapted to the dark for $1 \mathrm{~min}$. The fluorescence variable ( $\mathrm{Fv}$ ) was calculated from the difference between $F_{m}$ and $F_{0}$. The $F_{v}$ and $F_{m}$ values were used to obtain the maximum photochemical efficiency of PSII (Fv/Fm) ratio.

Enzyme assay
Assaying catalase: Catalase (EC-1.11.1.6) was assayed according to Kato and Shimizu (16) by spectrophotometric measuring the initial rate of disappearance of $\mathrm{H}_{2} \mathrm{O}_{2}\left(\mathrm{U} \mathrm{mL}^{-1}\right)$.

Assaying peroxidase: Peroxidase (EC 1.11.1.7) activity was measured according to Kato and Shimizu (16). Enzyme activity was expressed in units of $\mu \mathrm{M}$ of the substrate converted per min per mg chlorophyll.

\section{Ascorbic acid Oxidase (AO)}

The activity of ascorbic oxidase (EC1.10.3.3) was assayed, according to Oberbacher and Vines (17). Enzyme activity was expressed in units of $\mu \mathrm{M}$ of the substrate converted per min. per gram f.wt.

\section{Determination of ascorbic acid (AA)}

Non-enzymatic antioxidant, ascorbic acid, was estimated, according to Oser (18). The ascorbic acid content was calculated as $\mathrm{mg} / \mathrm{g}$ f.wt using a calibration curve of ascorbic acid.

\section{Results: \\ Effect of light intensity on growth parameters}

Table 1 shows the effect of light intensity (25 and $70 \mu \mathrm{mol} \mathrm{m} \mathrm{m}^{-2} \mathrm{~s}^{-1}$ ) on the growth parameters of Dunaliella parva. It is clear from the results that there was a decrease in cell number at a light intensity of $25 \mu \mathrm{mol} \mathrm{m} \mathrm{m}^{-2} \mathrm{~s}^{-1,}$ which amounted to $14.39 \%$, and a slight decrease $(3.03 \%)$ at $70 \mu \mathrm{mol}$ $\mathrm{m}^{-2} \mathrm{~s}^{-1}$ as compared with control, meanwhile the decrease in cell number at $\left(25 \mu \mathrm{mol} \mathrm{m} \mathrm{m}^{-2} \mathrm{~s}^{-1}\right)$ was accompanied by a decrease in the relative growth $\left(\mathrm{K}^{\prime}\right)$, the number of recycling, and the mean growth rate $\left(\mathrm{R}^{\prime}\right)$.

Table 1. Effect of light intensity on growth parameters of Dunaliella parva after 10 days of growth

\begin{tabular}{|c|c|c|c|c|c|c|}
\hline $\begin{array}{l}\text { Light intensity } \\
\left(\mu \mathrm{mol} \mathrm{m^{-2 }} \mathrm{s}^{-1}\right)\end{array}$ & Cell no. $* 10^{6} / \mathrm{ml}$ & $\mathbf{K}^{\prime}$ & G & No. of recycling & $\mathbf{R}$ & $\mathbf{R}^{\prime}$ \\
\hline 25 & $1.13 \pm 0.01$ & 0.067 & 4.473 & 2.235 & 0.180 & 0.223 \\
\hline 40 (control) & $1.32 \pm 0.04$ & 0.074 & 4.065 & 2.459 & 0.489 & 0.245 \\
\hline 70 & $1.28 \pm 0.05$ & 0.072 & 4.140 & 2.415 & 0.312 & 0.241 \\
\hline
\end{tabular}

Each value is the mean of five readings \pm standard deviation. $K^{\prime}=$ the relative growth, $G=$ generation time, $R=$ rate of growth and $R^{\prime}=$ mean growth rate.

\section{Effect of light intensity on photosynthetic pigments} and photosynthetic activity $\left(F_{V} / F_{m}\right)$

The data in Fig. 1 (a-c) revealed a highly significant decrease in the content of Chl.a in response to the light intensity of (25 and 70) $\mu \mathrm{mol}$ $\mathrm{m}^{-2} \mathrm{~s}^{-1,}$ amounting to 44.07 and $51.95 \%$, respectively as compared with control. The Chl. $b$ content was highly significantly decreased by 7.89 and $26.13 \%$ as compared with control on exposure of $D$. parva to the intensity of 25 and $70 \mu \mathrm{mol} \mathrm{m}^{-2} \mathrm{~s}^{-}$
${ }^{1}$, orderly compared with the control. Exposure of Dunaliella cells to the light intensity of 25 and 70 $\mu \mathrm{mol} \mathrm{m} \mathrm{m}^{-2} \mathrm{~s}^{-1}$ induced a highly significant decrease in carotenoids content, reaching 19.99 and $33.71 \%$, respectively, relative to the control. Furthermore, total chlorophyll was significantly decreased by $31.78 \%$ and $42.84 \%$, respectively, at 25 and 70 $\mu \mathrm{mol} \mathrm{m} \mathrm{m}^{-2} \mathrm{~s}^{-1}$ compared with control. Concerning Chl. $a /$ Chl. $b$ ratio, exposure of the alga either to light intensity of 25 or $70 \mu \mathrm{mol} \mathrm{m} \mathrm{m}^{-1}$ had resulted in a highly significant decrease of 39.28 and 34.32 
$\%$, respectively, with respect to the control. Meanwhile, the total chlorophyll/carotenoids ratio was significantly decreased by $13.75 \%$, at the light intensity of $70 \mu \mathrm{mol} \mathrm{m} \mathrm{m}^{-2} \mathrm{~s}^{-1}$ as compared to the control. On the other hand, low light intensity (25 $\left.\mu \mathrm{mol} \mathrm{m}{ }^{-2} \mathrm{~s}^{-1}\right)$ did not induce any significant change in the ratio of total chlorophyll/carotenoids.
Regarding the photosynthetic efficiency of the photosystem II as indicated by the $\left(\mathrm{F}_{\mathrm{v}} / \mathrm{F}_{\mathrm{m}}\right)$, it was high significantly decreased by $30.38 \%$, at $70 \mu \mathrm{mol}$ $\mathrm{m}^{-2} \mathrm{~s}^{-1}$, compared with the control. However, there was no significant change in $\mathrm{F}_{\mathrm{V}} / \mathrm{F}_{\mathrm{m}}$ at the low light intensity $\left(25 \mu \mathrm{mol} \mathrm{m}^{-2} \mathrm{~s}^{-1}\right)$.
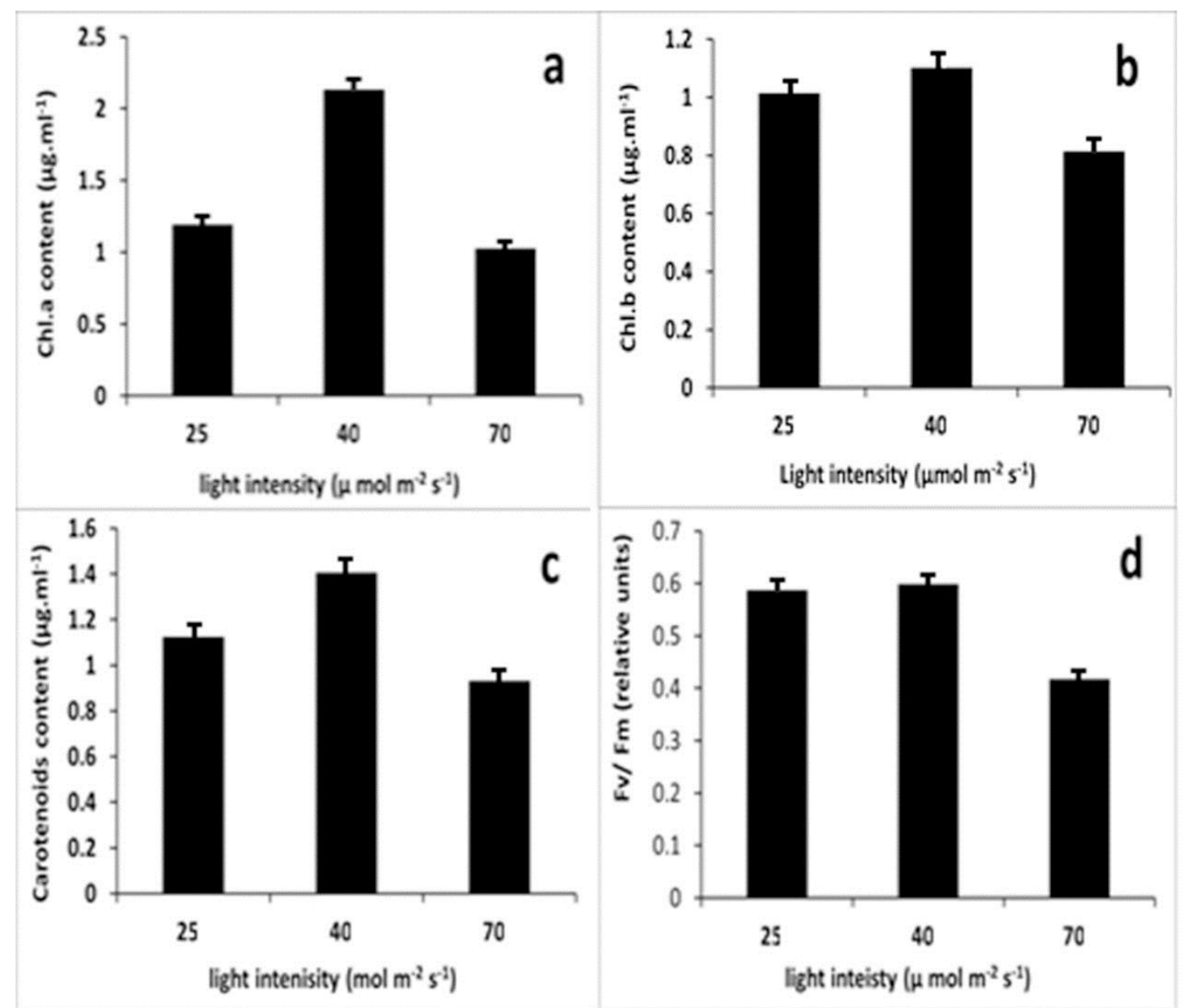

Figure 1. Effect of light intensity on pigments content of Dunaliella parva after 10 days of incubation. (a) Chlorophyll $a$, (b) Chlorophyll $b$, (c) Carotenoid and (d) Photosynthetic efficiency $F_{\mathrm{v}} / F_{\mathrm{m}}$

Effect of light intensity on the activity of enzymatic and nonenzymatic antioxidants.

The effect of light intensity on the activity of antioxidant enzymes and non-enzymatic antioxidants (Ascorbate) is presented in Fig. 2. The current results indicated that the low light intensity $\left(25 \mu \mathrm{mol} \mathrm{m} \mathrm{m}^{-2} \mathrm{~s}^{-1}\right)$ did not induce any significant change in the activity of all antioxidant enzymes (Catalase, Peroxidase, and ascorbic oxidase) and the content of non-enzymatic antioxidant (Ascorbate).
The high light intensity $70 \mu \mathrm{mol} \mathrm{m} \mathrm{m}^{-2} \mathrm{~s}^{-1}$, has significantly increased the activity of both catalase and peroxidase and the content of ascorbate. The percentage of stimulation was 38.25 and $21.93 \%$, for catalase and peroxidase, respectively, compared with control, and the content of ascorbate was increased by $46 \%$. However, the activity of ascorbic acid oxidase was reduced by $18.44 \%$ with respect to the control. 

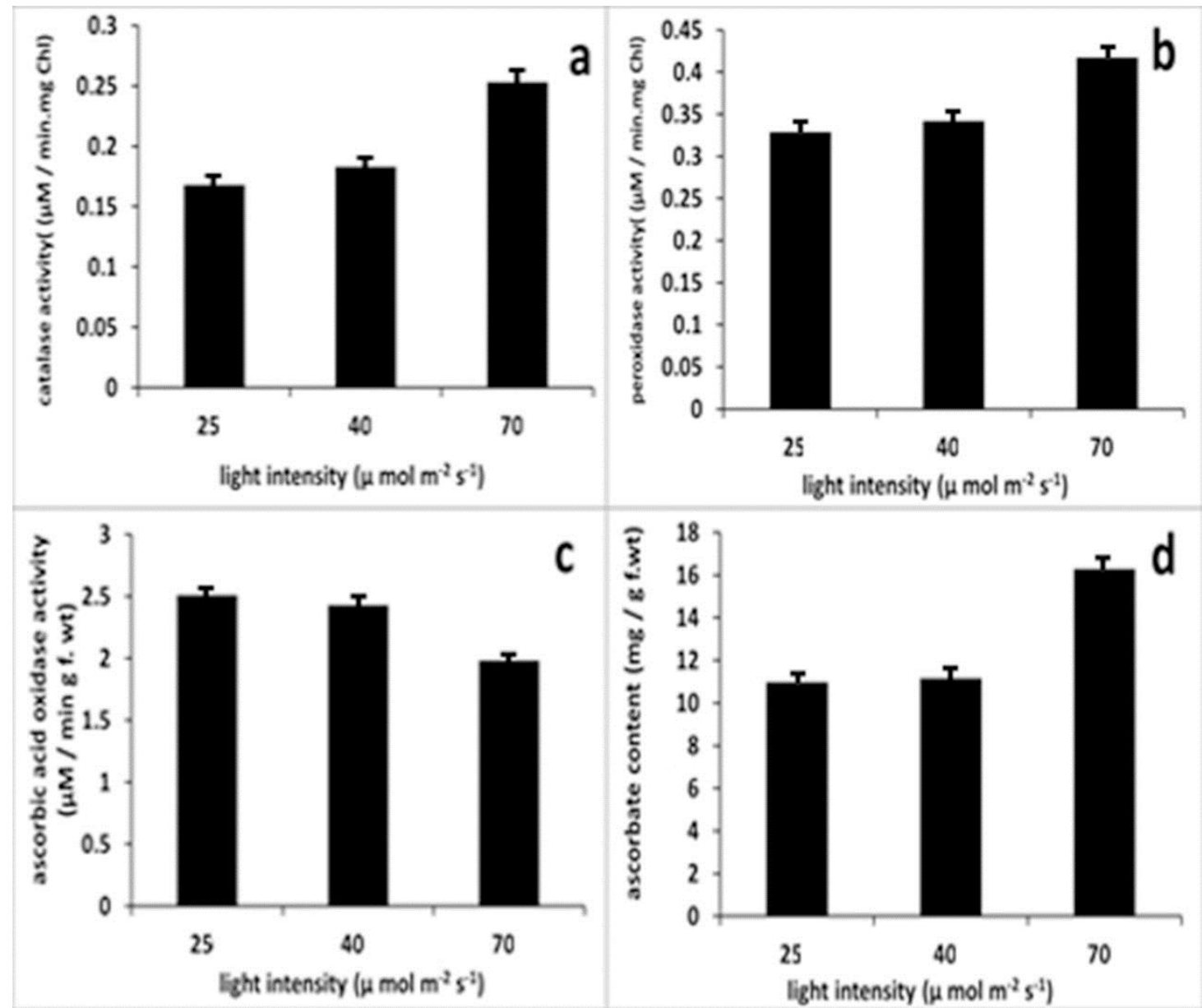

Figure 2. Effect of light intensity on the activity of enzymes and nonenzymatic $n$ antioxidant of Dunaliella parva (a) Catalase, (b) peroxidase, (c) Ascorbic acid oxidase and (d) Ascorbate content.

\section{Effect of light quality on cell number of Dunaliella} parva

Table 2 shows the effect of different light qualities (White light (WL) control, Blue light (BL), Green light (GL), and red light (RL)) on the cell number. The data revealed that there was a decrease in cell number under (BL), (RL), and (GL) reaching
40.82, 48.30, and $64.63 \%$, respectively, as compared with its corresponding value of the control (WL). Meanwhile, the decrease in cell number under (BL), (GL), and (RL) was accompanied by a decrease in the relative growth $\left(\mathrm{K}^{\prime}\right)$, number of recycling, and the mean growth rate ( $\left.\mathrm{R}^{\prime}\right)$.

Table 2. Effect of light quality on growth parameters of Dunaliella parva after 10 days of incubation

\begin{tabular}{ccccccc}
\hline Light quality & Cell no. ${ }^{*} \mathbf{1 0} / \mathbf{m l}$ & $\mathbf{K}^{\prime}$ & $\mathbf{G}$ & no of recycling & R & $\mathbf{R}^{\prime}$ \\
\hline White (control) & $1.47 \pm 0.01$ & 0.078 & 3.824 & 2.614 & 0.395 & 0.261 \\
\hline Blue & $0.87 \pm 0.08$ & 0.055 & 5.381 & 1.858 & 0.330 & 0.185 \\
\hline Red & $0.76 \pm 0.05$ & 0.050 & 6.012 & 1.663 & 0.233 & 0.166 \\
\hline Green & $0.52 \pm 0.09$ & 0.033 & 8.963 & 1.115 & 0.137 & 0.111 \\
\hline
\end{tabular}

Each value is the mean of five readings \pm standard deviation. $\mathrm{K}^{\prime}=$ The relative growth, $\mathrm{G}=$ Generation time, $\mathrm{R}=$ Rate of growth and $\mathrm{R}^{\prime}=$ Mean growth rate.

Effect of light quality on pigments content and photosynthetic activity $\left(F_{V} / F_{m}\right)$ of Dunaliella parva

The changes in Chl.a, Chl.b, carotenoids, total Chl., Chl. $a / \mathrm{Chl} . b$ and total Chl./carotenoids of D. parva under light spectra (BL), (RL), and (GL) are presented in Table 3. The present results indicated that the content of Chl.a was significantly decreased by $10.30,25.56$, and $31.95 \%$, under BL,
$\mathrm{RL}$ and GL, orderly relative to the control. In the meantime, BL, RL, and GL induced a highly significant decrease in chl. $b$ content, which reached $7.09,26.15$, and $38.31 \%$, respectively, compared with the control. The carotenoids content was also significantly decreased under BL, RL, and GL. The percentage of decrease was $16.56,27.70$, and 34.65 $\%$, respectively with respect to the control. The data 
also revealed that the total chl. was significantly decreased below the control value under all light spectra. The results indicated that no change in the ratio of chl. $a /$ chl. $b$, under BL, RL, and GL. The ratio of total chlorophyll/carotenoids was significantly increased by $8.81,13.65 \%$ under BL, and RL, respectively compared with the control. On the other hand, this ratio was significantly decreased by $8.86 \%$ under (GL) with respect to control. Concerning the photosynthetic efficiency of PSII $\left(\mathrm{F}_{\mathrm{V}} / \mathrm{F}_{\mathrm{m}}\right)$, the data indicated a highly significant decrease in $F_{V} / F_{m}$ under $B L, G L$, and RL. The percentage of decrease was 8.11, 17.40, and 52.80 $\%$, orderly at $\mathrm{BL}, \mathrm{RL}$, and GL, relative to the control.

Table 3. Effect of different light quality on pigments content and photosynthetic activity $\left(\mathbf{F}_{\mathrm{v}} / \mathbf{F}_{\mathrm{m}}\right)$ of Dunaliella parva after 10 days of growth

\begin{tabular}{|c|c|c|c|c|c|c|c|}
\hline Light quality & $\begin{array}{c}\text { Chl.a } \\
\left(\mu \mathrm{g} \cdot \mathrm{ml}^{-1}\right)\end{array}$ & $\begin{array}{c}\text { Chl. } b \\
\left(\mu \mathrm{g} \cdot \mathrm{ml}^{-1}\right)\end{array}$ & $\begin{array}{l}\text { Carot. } \\
\left(\mu \mathrm{g} \cdot \mathrm{ml}^{-1}\right)\end{array}$ & $\begin{array}{c}\text { total } \\
\text { chlorophyll } \\
\left(\mu \mathrm{g} \cdot \mathrm{ml}^{-1}\right)\end{array}$ & Chl. $a / b$ & $\begin{array}{c}\text { Total } \\
\text { chlorophyll/ } \\
\text { carotenoids }\end{array}$ & $\mathbf{F}_{\mathrm{V}} / \mathbf{F}_{\mathrm{m}}$ \\
\hline $\begin{array}{c}\text { White } \\
\text { (control) }\end{array}$ & $\begin{array}{c}2.019 \pm \\
0.092\end{array}$ & $\begin{array}{c}1.044 \pm \\
0.03\end{array}$ & $\begin{array}{c}1.498 \pm \\
0.01\end{array}$ & $\begin{array}{c}3.062 \pm \\
0.157\end{array}$ & 1.936 & 2.044 & $\begin{array}{c}0.678 \\
\pm 0.001\end{array}$ \\
\hline Blue & $\begin{array}{c}1.811 * * * \pm \\
0.011\end{array}$ & $\begin{array}{c}0.970 \pm \\
0.011^{(\mathrm{ns})}\end{array}$ & $\begin{array}{c}1.250 * * * \pm \\
0.005\end{array}$ & $\begin{array}{c}2.781 * * * \pm \\
0.008\end{array}$ & $1.866^{(\mathrm{ns})}$ & $2.224 *$ & $\begin{array}{c}0.623 * * * \\
\pm 0.002\end{array}$ \\
\hline Red & $\begin{array}{c}1.503 \pm \\
0.009 * * *\end{array}$ & $\begin{array}{c}0.771 \pm \\
0.011 * * *\end{array}$ & $\begin{array}{c}1.083 \pm \\
0.005^{* * *} \\
\end{array}$ & $\begin{array}{c}2.274 * * * \pm \\
0.021\end{array}$ & $1.948^{(\mathrm{ns})}$ & $2.323^{*}$ & $\begin{array}{c}0.560 * * * \\
\pm 0.001\end{array}$ \\
\hline Green & $\begin{array}{c}1.374 * * * \pm \\
0.009\end{array}$ & $\begin{array}{c}0.644 * * * \pm \\
0.003 \\
\end{array}$ & $\begin{array}{c}0.979 * * * \pm \\
0.007 \\
\end{array}$ & $\begin{array}{c}2.018 * * * \pm \\
0.020\end{array}$ & $2.134^{(\mathrm{ns})}$ & $1.863 *$ & $\begin{array}{c}0.320 * * * \\
\pm 0.0005 \\
\end{array}$ \\
\hline F value & 115.51 & 83.14 & 2396.28 & 106.79 & 33.54 & 56.16 & 1783.98 \\
\hline $\mathbf{P}$ & 0.0001 & 0.0001 & 0.0001 & 0.0001 & 0.0001 & 0.0001 & 0.0001 \\
\hline LSD & 0.129 & 0.095 & 0.021 & 0.217 & 0.094 & 0.128 & 0.017 \\
\hline
\end{tabular}

Each value is the mean of three readings \pm standard deviation.

One way analysis of variance (ANOVA) $\left(* * *\right.$ highly significant at $\mathrm{P} \leq 0.05$ and ${ }^{(\mathrm{ns})}$ non-significant at $\left.\mathrm{P}>0.05\right)$.

Effect of light spectra on the antioxidant and nonantioxidant enzymes of Dunaliella parva:

Table 4 shows the influence of light spectra on the activity of antioxidant enzymes (Catalase, Peroxidase, and ascorbic acid oxidase) and the content of non- enzymatic antioxidant (ascorbate). It is evident from the results that the activity of catalase was stimulated under GL and RL. The magnitude of increase was 18.01 and $12.42 \%$, orderly compared with the control. However, BL did not induce any significant change in catalase activity. Peroxidase activity was significantly stimulated under GL and RL, but there was no significant change under BL. The percentage of stimulation under GL and RL reached 18.58 and $4.10 \%$, with respect to the control. Regarding the activity of ascorbic acid oxidase, the results revealed no significant change under BL. On the contrary, under GL and RL, there was a highly significant decrease in the activity of ascorbic acid oxidase, the highest magnitude of inhibition was recorded under GL, and it amounted to $50.21 \%$, relative to the control.

Table 4. Effect of light spectra on the antioxidant enzymes (catalase, peroxidase, ascorbic acid oxidase) and non-antioxidant (ascorbate) of Dunaliella parva

\begin{tabular}{ccccc}
\hline Light quality & $\begin{array}{c}\text { Catalase }(\boldsymbol{\mu M} / \mathbf{m i n} . \mathbf{m g} \\
\mathbf{C h l})\end{array}$ & $\begin{array}{c}\text { Peroxidase }(\boldsymbol{\mu M} / \mathbf{m i n} . \mathbf{m g} \\
\mathbf{C h l})\end{array}$ & $\begin{array}{c}\text { Ascorbic acid oxidase } \\
(\boldsymbol{\mu M} / \mathbf{m i n} \mathbf{g} \mathbf{f} \mathbf{w t})\end{array}$ & $\begin{array}{c}\text { Ascorbate }(\mathbf{m g} / \mathbf{g} \\
\mathbf{f . w t})\end{array}$ \\
\hline $\begin{array}{c}\text { White } \\
(\mathbf{c o n t r o l})\end{array}$ & $0.161 \pm 0.022$ & $0.366 \pm 0.006$ & $2.396 \pm 0.8$ & $11.250 \pm 0.05$ \\
\hline Blue & $0.167 \pm 0.12^{(\mathrm{ns})}$ & $0.370 \pm 0.003^{(\mathrm{ns})}$ & $2.383 \pm 0.1^{(\mathrm{ns})}$ & $11.361 \pm 0.09^{(\mathrm{ns})}$ \\
\hline Red & $0.181 \pm 0.011^{* * *}$ & $0.381 \pm 0.006^{* * *}$ & $1.984 \pm 0.8^{* * * *}$ & $11.514 \pm 0.04^{*}$ \\
\hline Green & $0.190 \pm 0.012^{* * *}$ & $0.434 \pm 0.03^{* * *}$ & $1.193 \pm 0.08^{* * *}$ & $13.284 \pm 0.1^{* * *}$ \\
\hline P & 0.002 & 0.0001 & 0.0001 & 0.0001 \\
\hline LSD & 0.02 & 0.013 & 0.223 & 0.204 \\
\hline
\end{tabular}

Each value is the mean of three readings \pm standard deviation. One way analysis of variance (ANOVA) (*** highly significant at $\mathrm{P} \leq$ 0.05 and $^{(\text {ns) }}$ non-significant at $\mathrm{P}>0.05$ ). 
Concerning the impact of light spectra on ascorbate, the results indicated that GL increased its content by $18.08 \%$. Also, RL exhibited a slightly significant increase in ascorbate content, relative to control, while BL had no significant effect.

\section{Discussion:}

Dunaliella is a halotolerant green alga that now belongs to the phylum Chlorophyta and family Dunaliellaceae (19). Cell number is a helpful indicator to clarify the role of biochemical mechanisms underlying the responses observed (20). The present results indicated that Dunaliella parva cells attained their maximum growth after 10 days of incubation. This result agreed with those of Taha et al., (21), who reported that at the $8-10^{\text {th }}$ day, the cells of Dunaliella salina were at their start of a stationary phase of growth and so harvested at this time. The results also indicated that there was a gradual and highly significant increase in all pigments (Chl. $a$, Chl. $b$ and carotenoids) with increasing time logical and expected due to an increase in living biomass. This may be related to the ability of new cells to synthesize pigments using nutrients derived from dead cells and/or the low degradation rate of pigments at a late stage of growth under normal conditions (22).

Light is the ultimate energy source for photosynthesis, and light intensity is one of the most important environmental factors for all photosynthetic organisms (3). In the present work, the cell number of Dunaliella parva was decreased by 14.39 and $3.03 \%$ at 25 and $70 \mu \mathrm{mol} \mathrm{m} \mathrm{m}^{-2} \mathrm{~s}^{-1}$ on the $10^{\text {th }}$ day of growth. This result was not in harmony with Zarandi Miandoab et al. (20), who found that the growth and division of Dunaliella salina were increased significantly under 1000 $\mu \mathrm{mol} \mathrm{m} \mathrm{m}^{-2} \mathrm{~s}^{-1}$. This may be related to adequate and effective cell adaptation (5). The growth rate of Dunaliella virids was extremely affected by light intensity; it increased from darkness to $70 \mu \mathrm{mol} \mathrm{m} \mathrm{m}^{-2}$ $\mathrm{s}^{-1}$ but decreased at $150 \mu \mathrm{mol} \mathrm{m} \mathrm{m}^{-2}(23)$.

A deep insight into the results of photosynthetic pigments showed that the content of all pigment fractions (Chl. $a$, Chl. $b$, Carotenoids, and total chlorophyll) were high significantly decreased under both light intensities (250 and 700 $\mu \mathrm{mol} \mathrm{m} \mathrm{m}^{-2} \mathrm{~s}^{-1}$ ). This finding is in accordance with the results of Ilkhnur et al. (24), who found a decrease of both chlorophylls and carotenoids contents with increasing light intensity (50-75) $\mu \mathrm{mol} \mathrm{m} \mathrm{m}^{-2} \mathrm{~s}^{-1}$. They also reported that chlorophyll a and carotenoids concentrations were the highest at the light intensity of $\left(50 \mu \mathrm{mol} \mathrm{m} \mathrm{m}^{-2} \mathrm{~s}^{-1}\right)$. They speculated that growth at higher light $\left(75 \mu \mathrm{mol} \mathrm{m} \mathrm{m}^{-2} \mathrm{~s}^{-1}\right)$ intensity was faster, so pigment accumulation could not be promoted by the adaptation of microalgae to high light, the dimensions of light-harvesting antenna lessen, and thylakoid membranes become more efficient, which is a natural process. During the so-called photoacclimation phenomenon, cellular chlorophyll components come to a minimum, and thylakoid membranes start to work more efficiently (25). In this respect, Aro et al. (26) reported that nonoptimal light intensity could adversely affect metabolism and excitation of the photosynthetic apparatus, which can induce photoinhibition, photodamage, and degradation of the photosynthetic proteins in the cell.

In addition, the results revealed that $\mathrm{Chl} a / b$ ratio was high and significantly decreased under both light intensities. This result was in agreement with the findings of Levy et al. (27), who reported that when Dunaliella bardawili grew under sunlight spectra with high light intensities $\mathrm{Chl} a / b$ ratio was decreased and accompanied by $60 \%$ increase in $\beta$ carotene. They further concluded that light is a limiting factor influencing pigment synthesis. However, the present data are not in agreement with the increase in carotenoids, as reported in the above- mentioned algae. This may be related to the ability of Dunaliella cells to adapt to different stresses as they have the mechanism to change their intracellular chemicals between glycerol and carotenoids (28).

The results indicated that photosynthetic efficiency $\mathrm{F}_{\mathrm{v}} / \mathrm{F}_{\mathrm{m}}$ was high and significantly reduced at both light intensities, but the magnitude of reduction was great at a high light intensity (70 umol $\mathrm{m}^{-2} \mathrm{~s}^{-1}$ ). Changes in light intensities during plant and algal growth results in a reversible structural and functional adjustment in the photosynthetic apparatus (29). Photosynthetic organisms acclimate to the level of irradiance by adjusting the size of the chlorophyll antenna associated with photosystems (30). When plants are grown under high light intensity, photosystems contain small antennas and relatively low amounts of Chl $b$ in comparison with low light intensity (31). Thus, the mechanism of chloroplast photoacclimation involving the regulation of Chl. $b$ biosynthesis and changing in chlorophyll antenna size is a dynamic irradiance dependent recovery response (6).

Endogenous antioxidant enzymes, such as catalase and peroxidase, play an important role in the repair of oxidative damage (32). When photosynthetic pigments absorb more energy than is used in photosynthesis, the excess electron reacts with the abundantly present oxygen under those conditions; the chlorophyll molecules coupled with 
the electron transport system are the primary source for the creation of singlet oxygen (33).

High irradiance also may lead to overreduction of the photosynthetic electron transport chain and hence increases the production of several free radicals referred to as reactive oxygen species (ROS) (20).

The increase in the activity of catalase, peroxidase, and ascorbate content in the present work may be due to the oxidative stress imposed on Dunaliella parva at the high light intensity. The abovementioned reasons for the production of ROS under high light intensity may account for the recorded stimulation of catalase and peroxidase activities and the increase in the content of ascorbate as a defense mechanism. Biological systems respond to elevated ROS levels by activating several antioxidative defense mechanisms. Because of the central role of photosynthesis, photosynthetic organisms had developed strategies to acclimate to a broad range of environmental conditions such as high light by modulating their metabolism (34).

Algal photosynthetic apparatus quickly adapt to radiation quality as well as to irradiance (35), light quality, and carbon source (36). The results of this study indicated that cell number was decreased under different light qualities in the following order BL $>$ RL $>$ GL compared with control. This may be related to the difference in energy provided by different light spectra. Overall, the white light, which has the energy for the activation of photosynthetic pigments, provides enough energy for optimal maintenance and growth (37). This suggests that the red part of the spectrum is not by itself able to support the growth, but is not inhibitory either to growth or to the maintenance of cell integrity. However, the energy is not enough for other essential metabolic processes (38), which explains the low cell number recorded under RL in the present work. On the other hand, blue light, which is absorbed by photosynthetic pigments, can run both the photosynthetic and respiratory cycles (39). As a result, the cell integrity process performed well in the BL. The lowest cell number recorded under green light may be related to very low energy reaching PSII via the reflection of GL by photosynthetic pigments.

This study indicated that the content of all pigment fractions (Chl. $a$, Chl. $b$ and carotenoids) was highly significantly decreased under all studied light spectra, with respect to white light, with the exception of Chl. $b$ under BL. This finding may be attributed to structural changes in chloroplastic thylakoid membranes and their integrity. In this respect, Dowidar (40) found that grana of
Chlamydomonas reinhardii were well organized under BL, but disorganized under RL. Also, Muthuvelan et al., (37) reported that RL induced the disorganization of thylakoid via the low energy provided to maintain cell integrity. Disorganization of thylakoid membranes, which is the protective system of photosynthetic pigments, may explain the recorded low content of all pigment fractions in this study.

Algal adaptation to different light spectra is known to induce variation in the thylakoid components, particularly the antennae size and a number of photosystem complex (25). The reduction in photosynthetic efficiency $\left(\mathrm{F}_{\mathrm{v}} / \mathrm{F}_{\mathrm{m}}\right)$, in the present work, under different light spectra was associated with a decrease in Chl. $b$ content. This result was in harmony with Dowidar (40) and Hamada et al. (36), who found high Chl. $b$ content in cells grown under BL and high Chl. $a$ concentration in those cells grown under RL. In addition, they found that Emerson enhancement and the fraction of photons delivered to PSII $(\beta)$ measured from cells grown under BL were significantly higher than under RL and were lower than those grown under WL.

Kowallik and Schürmann (41) reported that high Chl.b concentration is necessary for an efficient function of PSII. On the other hand, Dowidar (40) reported that the fraction of photons delivered to PSI $(\alpha)$ and absorbed by RL grown cells might result in an increased cyclic flow of PSI. Consequently, electron flow from PSII may slow down the oxygen evolution of these cells when compared with those under WL, even though RL contains both wavelengths required for stimulation of PSII and PSI (40).

Blue light is known to stimulate protein synthesis (38), and the metabolic processes and morphological development rely on the role of protein and lipid (37). In addition, the nonsignificant change in the antioxidant system in the present work may be explined by the enough energy provided to the cell by BL for metabolic activities. On the other hand, the energy for the photosynthesis process may not be available in the red light; therefore, it might alter the products of photosynthesis in such a way to halt growth and continue the cell maintenance process with the limited source of other substances (37). It has been shown that such loss cannot be compensated by supplementation of growth medium with sugar acetate or amino acids (42). This low energy provided by RL and GL might impose a stress on the studied organism, which responds by stimulating the activity of catalase and peroxidase and increased the content of ascorbate. 


\section{Conclusion:}

In conclusion, the optimal growth and highest photosynthetic efficiency $(\mathrm{Fv} / \mathrm{Fm})$ of the marine alga Dunaliella parva were recorded at a light intensity of $40 \mu \mathrm{mol} \mathrm{m}^{-2} \mathrm{~s}^{-1}$, white light, and $1.25 \mathrm{M} \mathrm{NaCl}$. The activity of antioxidant enzymes, including catalase and peroxidase and ascorbate content, showed the highest values of 0.190 $\mu \mathrm{M} / \mathrm{min} . \mathrm{mg} \mathrm{Chl}, 0.434$ and $13.284 \mathrm{mg} / \mathrm{g}$ fresh weight, respectively under the green light. The induction in catalase and peroxidase activity indicated that $D$. parva responded to low energy provided by red light and green light to overcome this environmental stress.

\section{Authors' declaration:}

- Conflicts of Interest: None.

- We hereby confirm that all the Figures and Tables in the manuscript are mine ours. Besides, the Figures and images, which are not mine ours, have been given the permission for republication attached with the manuscript.

- Ethical Clearance: NA.

\section{References}

1. Rad F, Aksoz N, Hejazi M. Effect of saltiness on the growth and production of $\beta$ - carotene in isolated Dunaliella sp. microalga from qom salt Lake of Iran. Int. J. Biosci. 2015; 6(2): 164-171.

2. Mingazzini M, Teresa M, Palumbo H. Open Mass Cultures of Marine Microalgae for Biodiesel Production: Laboratory Approach to Study Species Competition in Mixed Cultures. Nat. Resour. 2015; 6: 174-180.

3. Xu Y, Ibrahim IM, Wosu CI, Ben-Amotz A, Harvey PJ. Potential of New Isolates of Dunaliella Salina for Natural $\beta$-Carotene Production. Biology. 2018; 7(1): 14.

4. Xi Y, Wang J, Chu Y, Chi Z, Xue Z. Effects of different light regimes on Dunaliella salina growth and $\beta$-carotene accumulation. Algal Research. 2020; 52; 102111.

5. Coesel S, Baumgartner A, Teles L, Ramos A, Henriques N, Cancela L, et al. Nutrient limitation is the main regulatory factor for carotenoid accumulation and for Psy and Pds steadystate transcript levels in Dunaliella salina (Chlorophyta) exposed to high light and salt stress. Marine Biotechnol. 2008; 10(5): 602- 611.

6. Masuda T, Tanaka A, Melis A. Chlorophyll antenna size adjustments by irradiance in Dunaliella salina involve coordinate regulation of chlorophyll a oxygenase (CAO) and Lhcb gene expression. Plant Mol. Biol. 2003; 51: 757-771.

7. Bohne F, Linden H. Regulation of carotenoid biosynthesis genes in response to light in Chlamydomonas reinhardtii. Biochimica et Biophysica Acta-Gene Structure and Expression. 2002; 1579: 26-34.
8. Park S, Lee Y, Jin E. Comparison of the responses of two Dunaliella strains, Dunaliella salina CCAP 19/18 and Dunaliella bardawil to light intensity with special emphasis on carotenogenesis. Algae 2013; 28(2): 203-211.

9. Korbee N, Mata M, Figueroa F. Photoprotection mechanisms against ultraviolet radiation in Heterocapsa sp. (Dinophyceae) are influenced by nitrogen availability Mycosporine-like amino acids vs. xanthophyll cycle. Am. Soc. Limnol. Oceanogrphy Inc. 2010; 55(2): 899-908.

10. Palacios YM, Vonshak, A, Beardall, J. Photosynthetic and growth responses of Nannochloropsis oculata (Eustigmatophyceae) during batch cultures in relation to light intensity. Phycologia. 2018; 57 (5): 492-502.

11. Loeblich L. Photosynthesis and pigments influenced by light intensity and salinity in the halophilic Dunaliella salina (Chlorophyta). J. Mar. Biol. Assoc.UK, 1982; 62: 493-508.

12. Vijaya V, Anand N. Blue light enhance the pigment synthesis in Cyanobacterium Anabaena ambiguo Rao (Nostacales). ARPN. J. Agric. Biol. Sci. 2009; 4(3): 36-43.

13. Robert R. Growth measurements. Division rate. In R.J. Sttein (ED). Physiological methods. Culture methods and growth measurements. Cambridge Univ. Press, Cambridge. 1979; 29: 311.

14. Fogg G.E. Algal Cultures and Phytoplankton Ecology. The University of Winsconsin Press: London. 1975; pp.7-45

15. Mckinney G. Absorption of light by chlorophyll solutions. J. Boil. Chem. 1941; 140: 315-322.

16. Kato M, Shimizu S. Chlorophyll metabolism in higher plants. VII. Chlorophyll degradation in senescing Tobacco leaves, phenolic-dependent peroxidative degradation. Canad. J. Bot. 1987; 65: 729-735.

17. Oberbacher M, Vines H. Spectrophotometric assay of ascorbic acid oxidase. Nature. 1963; 197: 1203-1204.

18. Oser, B. Hawks physiological chemistry, McGrawHills, New York, 1979.

19. Garcia F, Freile-Pelegrin Y, Robledo D. Physiological characterization of Dunaliella sp. (Chlorophyta, Volvocales) from Yucatan, Mexico. Bioresource Tech. 2007; 98: 1359-1365.

20. Zarandi M L, Hejazi M, Bagherieh-Najjar M, Chaparzadeh N. Light intensity effects on some molecular and biochemical characteristics of Dunaliella salina. Iran. J. Plant Physiol. 2015; 5(2): 1311- 1321.

21. Taha O, Abo El-Kheir W, Hammouda F, Abd ElHady H. Production of B-carotene and glycerol from Dunaliella bardawil and D. salina isolated from the Egyptian wetlands Qarun and Bardawil. International Conference on Ecological, Environmental and Biological Sciences (ICEEBS-2012), Dubai; 2012.

22. Taha H. Massive production of some economically important metabolic compounds in Dunaliella salina. M.Sc. Thesis. Fac. of Sci. Alex. Univ., Egypt, 1997.

23. Gordillo F, Goutx M, Figueroa F, Niell F. Effects of light intensity, $\mathrm{CO}_{2}$ and nitrogen supply on lipid class 
composition of Dunaliella viridis. J. Appl. Phycol. 1998; 10:135-144.

24. Ilkhnur A, Cirik S, Goksan T. Effect of light intensity, salinity and temperature on growth in Camalt strain of Dunaliella viridis Teodoresco from Turkey. J. Biol. Sci. 2008; 8:1356-1359.

25. Perez-Boerema A, Klaiman D, Caspy I, Netzer-El SY, Amunts A, Nelson N. Structure of a minimal photosystem I from the green alga Dunaliella salina. Nature Plants. 2020; 6: 321-32.

26. Aro E, Virgin I, Andersson B. Photoinhibition of photosystem II. Inactivation, protein damage and turnover. BBA- Bio. Energetics. 1993; 1143:113-134.

27. Levy H, Tal T, Shais A, Zamir A. The photosynthetic response of Dunaliella bardawil to the changes in the sunlight spectrum under field conditions. J. Biol. Chem. 1993; 268: 20892-20896.

28. Pourkarimi S, Hallajisani A, Alizadehdakhel A, Nouralishahi A, Golzary A. Factors affecting production of beta-carotene from Dunaliella salina microalgae. Biocatal Agric Biotechnol. 2020; 29: 101771

29. Anderson J. Photoregulation of the composition, function, and structure of thylakoid membranes. Ann. Rev. Plant Physiol. 1986; 37: 93-136.

30. Negi S, Perrine S, Friedland N, Kumar A, Tokutsu R, Minagawa J, et al. Light regulation of light-harvesting antenna size substantially enhances photosynthetic efficiency and biomass yield in green algae. The Plant Journal 2020; 103: 584-603.

31. Larsson U, Anderson J, Andersson B. Variations in the relative content of the peripheral and inner lightharvesting chlorophyll a/b-protein complex (LHCII) subpopulations during thylakoid light adaptation and development. BBA-Bioenergetics. 1987; 894: 69-75.

32. Wu H, Wang CJ, Bian XW, Zeng SY, Lin KC, Wu B, et al. Nematicidal efficacy isothiocyanates against root-knot nematode Meloidogyne Javanica in Cucumber. Crop. Port. 2011; 30: 33-37.

33. Ramel F, Mialoundama A, Havaux M. Nonenzymic carotenoid oxidation and photooxidative stress signalling in plants. J. Exp. Bot. 2013; 64:799-805.
34. Pfannschmidt T. Chloroplast redox signals: how photosynthesis controls its own genes. Trends Plant Sci. 2003; 8: 33-41.

35. Stetsenko LA, Pashkovsky PP, Voloshin RA, Kreslavski VD, Kuznetsov LV, Allakhverdiev SI. Role of anthocyanin and carotenoids in the adaptation of the photosynthetic apparatus of purple- and greenleaved cultivars of sweet basil (Ocimum basilicum) to high-intensity light. Photosynthetica. 2020; 58 (4): 890-901.

36. Hamada E, Dowidar S, Punnet K. Influence of spectral range and carbon and nitrogen sources on oxygen evolution and Emerson enhancement in Chlamydomonas renhardtii. Biol. Plant. 2003; 46(3): 398-397.

37. Muthuvelan B, Noro T, Nakamura K. Effect of light quality on the cell integrity in marine alga Ulva pertusa (Chlorophyceae). Indian J. Marine Sci. 2002; 31(1): 21-25.

38. Wang S, Verma SK, Said IH, Thomsen L, Ullrich MS, Kuhnert N. Changes in the fucoxanthin production and protein profiles in Cylindrotheca closterium in response to blue light-emitting diode light. Microbial cell factories. 2018 Dec;17(1):1-3.

39. Kowallik W. Blue light effects on respiration. Annus. Rev. Plant Physiol. 1982; 33: 51-72.

40. Dowidar S. Effect of growth conditions on carbon assimilation and oxygen evolution under the influence of different light qualities in Chlamydomonas reinhardtii. Thesis submitted to the faculty of science Tanta University, 1990.

41. Kowallik W, Schürmann R. Chlorophyll a/chlorophyll b ratios of Chlorella vulgaris in blue or red light. -In: Senger, H. (ed.) Blue light Effects in Biological Systems. p. 352-358. Springer- Verlag, Berlin - Heidelberg - New York, 1984.

42. Terborgh J. Effects of red and blue light on the growth and morphogenesis of Acetabularia crenulate. Nature. 1965; 25: 1360-1363. 


\section{تأثير أطوال موجات ضوئية مختلفة على النمو ونشاط الإنزيمات والبناء الضوئي للطحالب البحرية الاقيقة}

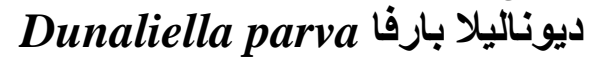

عزة حماد

سمحة دويدار

مصطفى محمد الشيخ

قسم النبات، كلية العلوم، جامعة طنطا، مصر.

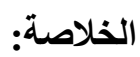

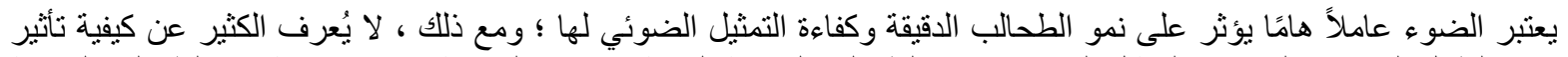

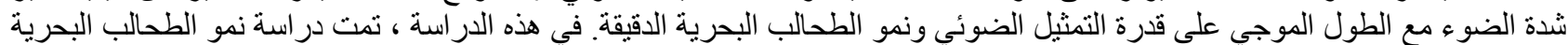

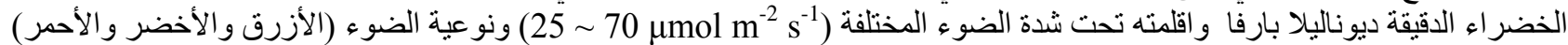
مقارنة بالضوء الأبيض عند

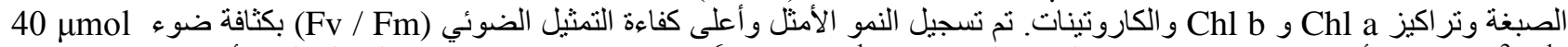

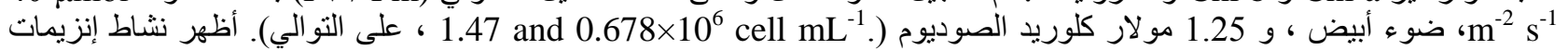

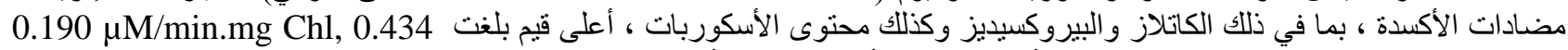
and 13.3 mg/g f.wt.

$$
\text { الكلمات المفتاحية: انزيمات الأكسدة- ديوناليلا بارفا- شدة الضوء- نوعيو الضوءـ البناء الضوئى لئ }
$$

